\title{
The 'Ura or Rimatara Lorikeet Vini kuhlii: its former range, present status, and conservation priorities.
}

\author{
GERALD MCCORMACK and JUDITH KÜNZLÉ
}

\section{Summary}

Fossils and other evidence from the Southern Cook Islands show that the Rimatara Lorikeet Vini kuhlii, known as the Kura, was widespread in the group during prehistoric times and, it was probably extirpated due to exploitation for its red feathers. Today, it survives only on Rimatara in the Austral Islands, where it is known as the 'Ura. On Rimatara during 5-11 August 1992 we saw/heard 263 'Ura, and estimated the total population at 900 birds. The mixed horticultural belt, about $32 \%$ of the island, was the most favoured habitat at 2.2 birds $\mathrm{ha}^{-1}$ and it supported about $61 \%$ of the total population. The species was uncommon in the coastal coconut plantations and central hills, and rare in the makatea/feo. Rats, especially Rattus rattus, have often been associated with the loss of forest birds on oceanic islands and $R$. rattus is thought to be responsible for the decline in other lorikeets of French Polynesia. A preliminary trapping study located $R$. norvegicus and $R$. exulans, but not $R$. rattus. The highest conservation priority should be given to confirming the absence of $R$. rattus on Rimatara and the implementation of a major quarantine programme to ensure that it is not accidentally introduced. We recommend reintroducing the lorikeet to islands within its former natural range.

\section{Introduction}

The lorikeets of French Polynesia are under threat within their natural ranges. The Blue Lorikeet Vini peruviana survives on five islands compared with more than a dozen islands 50 years ago, while the Ultramarine Lorikeet Vini ultramarina survives on only one island compared with three islands 20 years ago (Unitt \& Varney in litt.). The Rimatara Lorikeet Vini kuhlii or 'Ura survives only on Rimatara, where it has been recorded as common (Seitre and Seitre 1991), although there were no quantitative data on its status.

The main environmental change leading to the recent decline of lorikeets of French Polynesia is thought to have been the accidental introduction of the ship rat Rattus rattus (Seitre and Seitre 1991, Unitt and Varney in litt.). This species, which is the most agile tree-climber of the three species of rat in Polynesia, has been widely associated with the decline of forest birds on oceanic islands (Atkinson 1985).

The aim of the present study was to review the former range of Vini kuhlii, assess its present status and consider measures to ensure its survival, including 


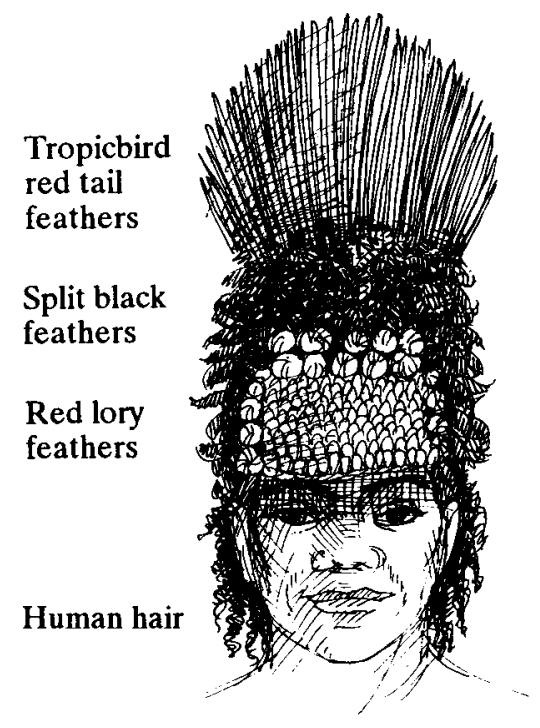

Aitutaki-Head-dress

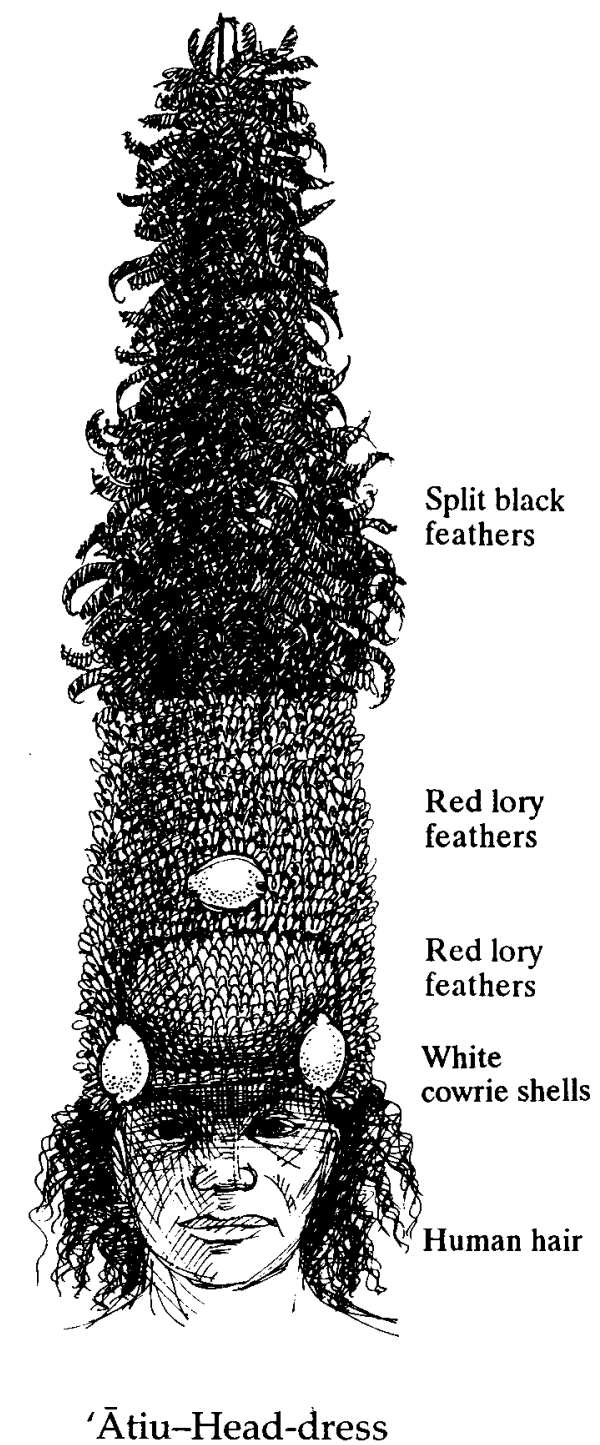

Figure $x$. Ceremonial head-dresses of the Cook Islands.

an evaluation of the likelihood of a successful reintroduction to islands within its former natural range.

\section{Past and present natural range}

In the Southern Cook Islands during ancient times, the small red feathers of the Kura were much prized for the adornment of people, god images, caps and elaborate ceremonial head-dresses, especially on Aitutaki, 'Ātiu and Ma'uke (Hiroa 1944) (Figure 1).

Although Hiroa (1944) reported a tradition of people going from Aitutaki to the atoll of Manuae to collect Kura feathers, there have been no reliable reports 
of Kura within the Cook Islands since the arrival of the missionaries in the 1820s. We conclude that the Kura was lost from the Cook Islands because of exploitation for its feathers in pre-missionary times, rather than because of the extensive replacement of native vegetation with exotic plants or the introduction of guns, cats and rats in the post-missionary era.

Recent studies of fossils and middens have shown that Vini kuhlii, a lorikeet with scarlet breast feathers, lived on Mangaia, 'Ātiu and Aitutaki (Steadman 1985, Steadman 1991). It can be concluded that the former Kura of the Cook Islands was Vini kuhlii (Steadman 1991) (Figure 2).

Savage (1962) summarizes oral traditions on the distribution of the Kura but, with the exception of the claim that it formerly lived on Rarotonga, little can be gained as he confuses the Cook Islands' Kura with the Aitutaki Kurāmo'o. The latter is Vini peruviana, which was recorded on Aitutaki in 1899 as the "common pet of the natives" (Townsend and Wetmore 1919), and it is probable that it was formerly introduced from the Society Group or northern Tuamotu. Remnants of Vini peruviana have not been found among the fossils, middens or artefacts of the Cook Islands and the occurrence of Vini kuhlii in the middens of Aitutaki indicates that the latter was the native lorikeet of the island. The two species would not have co-existed on the small island as they would have been in direct competition for food and nest sites, and it can be concluded that Vini peruviana was introduced after the loss of $V$. kuhlii.

Within its former natural range Vini kuhlii survives only on the island of Rimatara in French Polynesia where it was traditionally protected by the Queen (Ari'i Vahine) (Seitre and Seitre 1991), and where it is known by the cognate 'Ura. To honour the conservational spirit of the people of Rimatara we favour the vernacular name Rimatara Lorikeet, rather than Kuhl's Lorikeet.

Outside its natural range the Rimatara Lorikeet survives on Teraina (Washington) and Tabuaeran (Fanning) in the Northern Line Islands where it was introduced prior to 1798 , as the pet of itinerant Tahitian workers (Forshaw 1978, Watling in litt.). The Kiribati Government is planning to re-settle people on these islands, and a conservation programme is being developed to protect the lorikeet (C. Wilson pers. comm.).

\section{Biogeographic features of Rimatara}

Rimatara is a circular raised-reef island about $3 \mathrm{~km}$ in diameter and about 800 ha in area. The ancient raised-reef, called makatea or feo, forms a coastal rampart to $16 \mathrm{~m}$ elevation and $0.5 \mathrm{~km}$ wide around the north-west half of the island, with a ragged gap around Anapoto village. This rugged terrain supports extensive indigenous forests and scrublands. On the south-east half of the island the makatea is almost entirely replaced by an extensive coastal plain of coral sand and rubble, typically $2 \mathrm{~m}$ elevation and covered in coconut plantations. Inland of the makatea and coastal plain there is a discontinuous ring of swamplands, commonly used for the cultivation of taro Colocasia esculenta.

The centre of the island is a radially dissected, deeply weathered volcanic hill reaching $84 \mathrm{~m}$ high. The upper parts, typically above $30 \mathrm{~m}$, are covered with fernlands (mainly Dicranopteris linearis), grasslands (especially Melinis minutiflora) and introduced forestry (mainly Paraserianthes falcataria). The low 


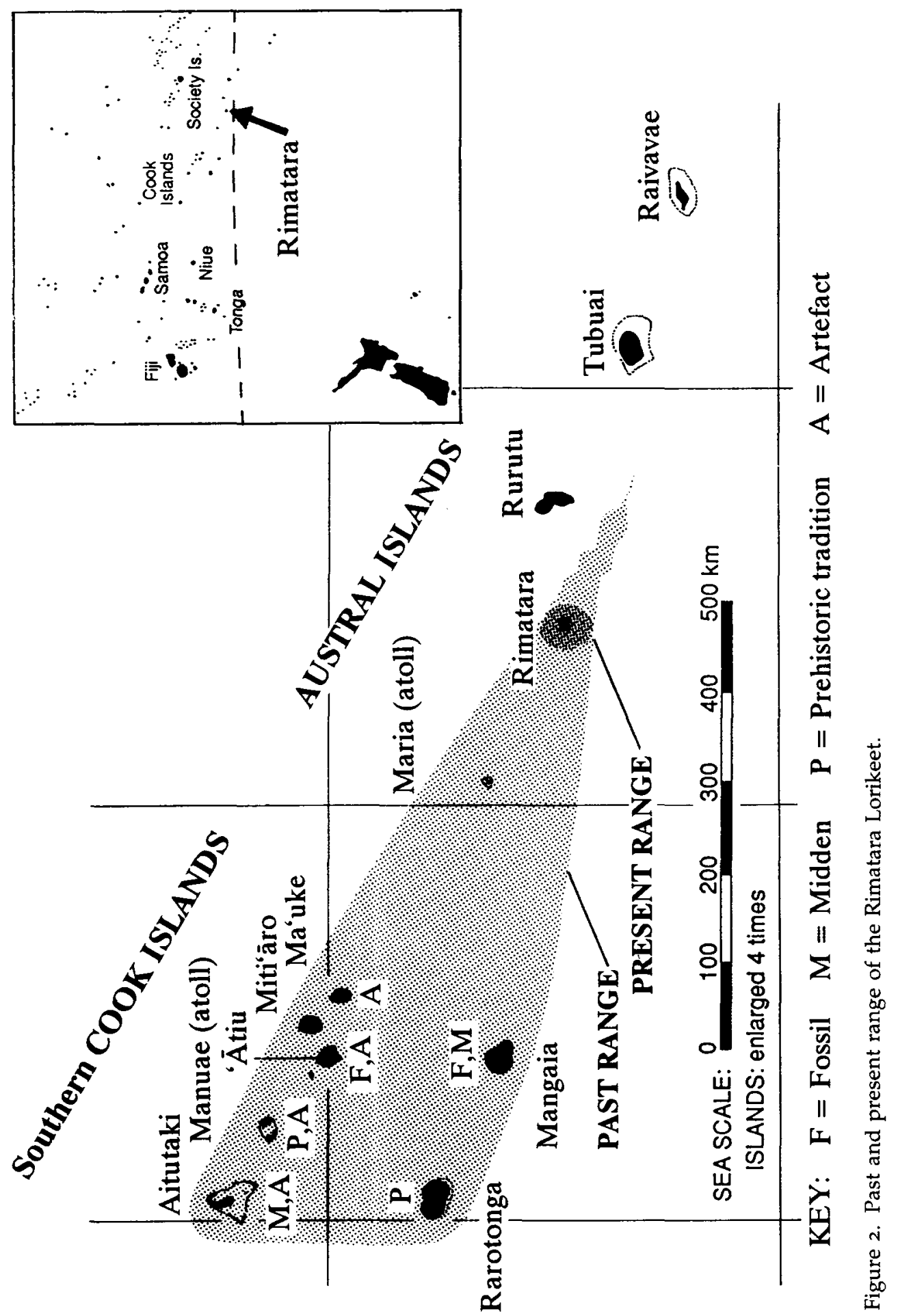




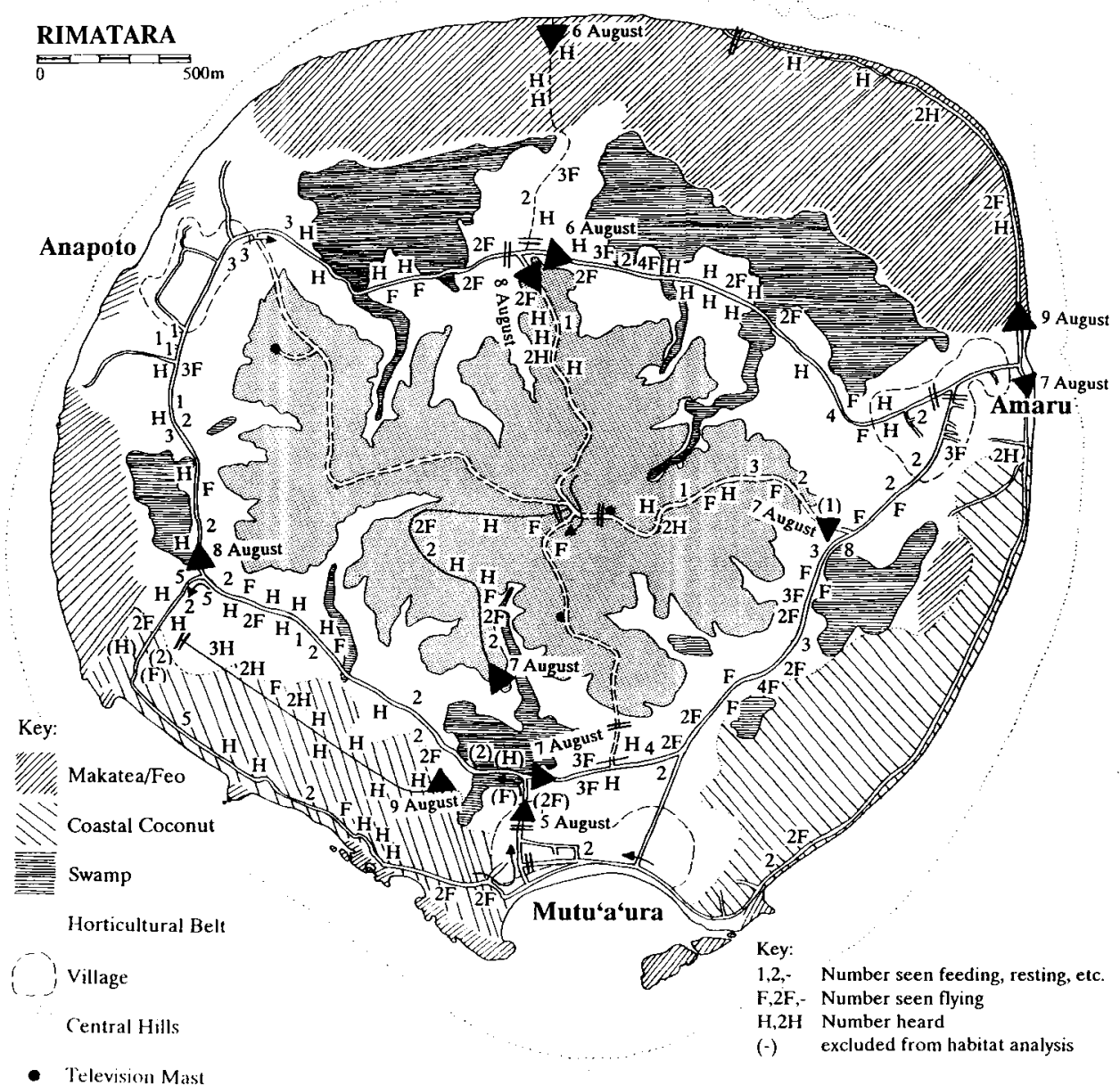

Figure 3. Locations of birds seen or heard.

volcanic slopes form the horticultural belt and are extensively planted in recently introduced food plants and coconut palms. This fertile belt covers about 250 ha or $32 \%$ of the island.

\section{Distribution and abundance}

Between 5 and 11 August 1992, during a walking survey of all the roads and the main vehicle tracks on Rimatara, we saw/heard 263 lorikeets (excluding records in repetitive samples). During the survey we slowly walked each track and sought to locate all birds within $50 \mathrm{~m}$ of the track, which was realistic in open areas, but overly optimistic in areas of dense vegetation. When birds were heard or seen close to the track the observer often spent a few minutes determining the size of the flock, sometimes going a few metres off the track.

The location of each bird was plotted on maps (scale $1: 10,000$ Service de l'Urbanisme 1988), and when the main vegetational communities were identified, the bird records were related to habitat (Figures 3 and 4). The 


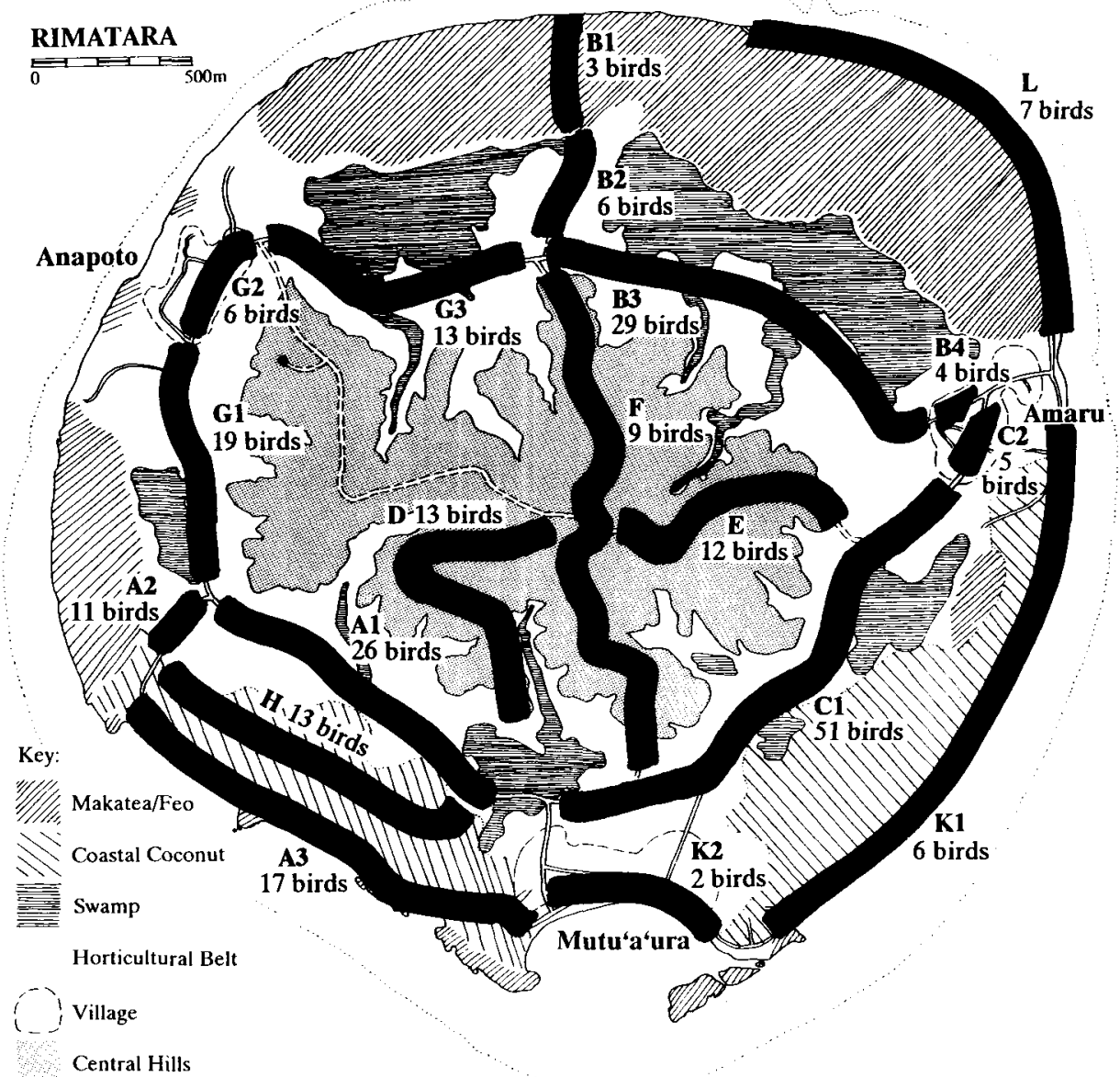

Figure 4. Habitats, transects and sample totals.

lorikeets were common in the mixed horticultural woodlands $\left(2.2 \mathrm{birds} \mathrm{ha}^{-1}\right)$, moderately common in the villages $\left(1.4 \mathrm{ha}^{-1}\right)$, uncommon in the central hills $\left(0.9 \mathrm{ha}^{-}\right)$and in the coastal coconut plantations $\left(0.8 \mathrm{ha}^{-1}\right)$ rare in the extensive makatea/feo $\left(0.6 \mathrm{ha}^{-1}\right)$, and absent from the swamplands (Table 1 ).

Table 1. Counts by Habitat, and estimates of densities and numbers

\begin{tabular}{llllllll}
\hline & $\begin{array}{l}\text { Total } \\
\text { sample } \\
\text { count } \\
\text { (birds) }\end{array}$ & $\begin{array}{l}\text { Total } \\
\text { transect } \\
\text { length } \\
(\mathrm{km})\end{array}$ & $\begin{array}{l}\text { Total } \\
\text { transect } \\
\text { area } \\
\text { (ha) }\end{array}$ & $\begin{array}{l}\text { Habitat } \\
\text { density } \\
\text { (birds/ } \\
\text { ha) }\end{array}$ & $\begin{array}{l}\text { Habitat } \\
\text { area } \\
\text { (ha) }\end{array}$ & $\begin{array}{l}\text { Esti- } \\
\text { mated } \\
\text { habitat } \\
\text { totals }\end{array}$ & $\begin{array}{l}\text { Percentage } \\
\text { of total } \\
\text { population }\end{array}$ \\
\hline Mixed horticulture & 155 & 7 & 70 & 2.2 & 250 & 550 & $61 \%$ \\
Villages & 17 & 1.2 & 12 & 1.4 & 30 & 42 & $5 \%$ \\
Central hills & 34 & 4 & 40 & 0.9 & 170 & 153 & $17 \%$ \\
Coastal coconut & 36 & 4.8 & 48 & 0.8 & 100 & 80 & $8 \%$ \\
Makatea & 10 & 2 & 20 & 0.5 & 160 & 80 & $9 \%$ \\
Swamps & & & & & 80 & 0 & \\
Estimated population based on a transect width of & $100 \mathrm{~m}$ & & 905 & $100 \%$ \\
\hline
\end{tabular}


Table 2. The sizes of groups

\begin{tabular}{cc}
\hline Group & Frequency \\
\hline 1 & 39 \\
2 & 48 \\
3 & 20 \\
4 & 7 \\
5 & 2 \\
6 & 0 \\
7 & 0 \\
8 & 2 \\
9 & 0 \\
10 & 1 \\
\hline
\end{tabular}

By estimating the areas of the different habitats we calculated the number of birds in each and the total population. The favoured mixed horticulture habitat, which covered about $32 \%$ of the island, supported about $61 \%$ ( 550 birds) of the estimated island total of 905 lorikeets.

Repetitive sampling along two transects (Figure 4) within the horticultural belt gave a measure of count-repeatability: along A1 the counts were 26,20 and 20 (at 14h15, 15h25 and ogh25 respectively), the lower figures being $77 \%$ of the maximum. Along $C_{1}$ the counts were 56 and 45 (at ogh50 and 11ho5), the lower figure being $80 \%$ of the higher. On average, because most transects were sampled once only, the counts used to estimate the population were conservative. The methodology is further biased conservatively in counting birds which were heard as single birds. Observations showed that the lorikeets were typically in groups of two or three, with most single observations reflecting constraints on searching time (Table 2).

The unknown factor in the population estimate was the mapping of the habitats. Further sampling would be required to determine whether the habitat estimates used were liberal or conservative.

\section{Food plants}

The 'Ura was recorded feeding on 12 species of flowering plant (Table 3). In addition, local people reported that it commonly fed on Coffea arabica flowers,

Table 3. Preferred food plants

\begin{tabular}{ll}
\hline Frequency & Species of flowering plant \\
\hline 33 & Inga (Inga ynga) \\
18 & Pacific Ironwood (Casuarina esquisetifolia) \\
18 & Falcata (Paraserianthes (Albizia) falcataria) \\
9 & Banana (Musa spp.) \\
8 & Mango (Mangifera indica) \\
7 & Kapok (Ceiba pentandra) \\
6 & Coconut Palm (Cocos nucifera) \\
3 & Chinese Hibiscus (Hibiscus rosa-sinensis) \\
4 & Indian Coral-tree (Erythrina variegata) \\
3 & Red-bead Tree (Adenanthera pavonina) \\
3 & Rose Apple (Syzygium jambos) \\
2 & Siris Tree (Albizia lebbeck) \\
\hline
\end{tabular}


which was not blooming during our visit, while Seitre and Seitre (1991) reported birds feeding on tree hibiscus Hibiscus tiliaceus flowers and the rotting leaf-borders of the fish-poison tree Barringtonia asiatica. In most cases the 'Ura fed on the nectar of flowers, although they also licked the leaf-stalks of some species (especially kapok and falcata), and in the case of the Pacific ironwood, they appeared to extract seeds from the fruit. With the exceptions of the coconut palm, Pacific ironwood and tree hibiscus, all the food plants are recent introductions.

\section{Nesting sites}

The residents generally believed that the 'Ura nested in holes in Barringtonia asiatica, Pisonia grandis and Paraserianthes falcataria, although we found nobody who had actually seen a nest. During our visit we saw a pair of birds burrowing into the end of a rotten branch of Hibiscus tiliaceus, although the activity was later abandoned. In contrast, Brunner (1972) reported that the species nested only in coconut palms and he listed January to March as the breeding season.

\section{Preliminary rat survey}

Only three traps were available for the survey. Rats were common in the main rubbish dump west of Amaru where we trapped four Norway rats Rattus norvegicus, while another was observed in Mutu'a'ura. During two trap-nights two Pacific rats Rattus exulans were caught in a house in Mutu'a'ura, and during 15 trap-nights two were caught in mixed horticultural plantations near the village. No ship rats were trapped during our survey.

Residents consider rat damage to be so uncommon that they do not trouble to put sheet-metal bands on coconut palms, as is the practice on many Pacific islands. This is a further indication of the absence of the ship rat, the species most often found living in the crowns of coconut palms (R. Hitchmough pers. comm.). We occasionally found fallen fruit of hard passionfruit Passiflora maliformis and Polynesia chestnut Inocarpus fagifer which had been eaten by rats, presumably by Rattus exulans. We tentatively conclude that $R$. rattus was absent from Rimatara during 1992, and this may be the main reason why the lorikeet is still abundant.

\section{Conservation strategy}

The Rimatara Lorikeet is vulnerable because it survives only on a single island within its formerly extensive natural range, and a detrimental change in the environment could lead to its loss on Rimatara. The most likely destructive change would be the accidental introduction of the ship rat, or if it is already present, an increase in its numbers. The main priority on Rimatara is to confirm the absence of the ship rat and to implement a programme to prevent its accidental introduction. If the ship rat is already present in small numbers, steps should be taken to eradicate it.

It is necessary to monitor the lorikeet population every two or three years, by comparing the maximum counts along the three transects $\mathrm{A}_{1}, \mathrm{C}_{1}$ and $\mathrm{G}$, 
in the horticultural belt. During these surveys it is recommended that the observers plot the estimated distance of all birds from the track to give greater flexibility in analyzing the results. When birds are heard close to the road the observers should move a few meters into the vegetation to record the number. The lorikeet could also be reintroduced to one of the islands within its former range.

In the belief that the Kura was lost from the Cook Islands because of pre-historic feather-collecting rather than some other environmental change, we considered the present environments to assess the likelihood of a successful reintroduction. A comparison of the present indigenous and introduced plants of Rimatara and the makatea islands of Mangaia, 'Ātiu and Ma'uke, showed great similarity and we conclude that these islands would provide adequate food and nest sites for a successful reintroduction.

Unlike Rimatara, the Cook Islands' makatea islands have the introduced Common Mynah Acridotheres tristis, which is known to disturb nesting landbirds. However, the Blue Lorikeet is common on Aitutaki (Wilson 1993) despite abundant mynahs, which were introduced in 1916 (McCormack 1993). The mynah is not likely to be a serious problem to the lorikeet, which is a very secretive nester.

Of the three vegetationally suitable makatea islands, ship rats have been caught on Mangaia (Rowe 1993) and there is strong circumstantial evidence of ship rats on Ma'uke. In contrast, an extensive trapping survey during 1994 on 'Átiu produced 78 Pacific rat but no ship rat (unpublished data). It is therefore likely that the Rimatara Lorikeet could be successfully reintroduced to 'Âtiu. The establishment of such a back-up population should be undertaken with as many pairs as possible to ensure a genetic diversity similar to the parent population.

The landbirds of the Cook Islands, including the introduced Common Mynah, do not carry any protozoan parasites (Steadman et al 1990), such as, Plasmodium relictum, the source of avian malaria which caused the extinction of several landbirds in the Hawaiian Islands this century (van Riper et al. 1986). The main mosquito vector, Culex quiquefasciatus, is present in the Cook Islands (McCormack, 1991) and the accidental introduction of the parasite could be disastrous for the indigenous birds, which presumably lack an acquired immunity. Although Rimatara, without recently introduced landbirds other than the fowl Gallus gallus, is probably free of avian malaria, any lorikeets obtained for reintroduction to the Cook Islands must be adequately quarantined.

\section{Acknowledgements}

We thank Tom and Ellen Winser (who sponsored the expedition on their yacht Ardevora); the Cook Islands Prime Minister, Sir Geoffrey Henry KBE, and his Cabinet; The Hunt-Commissaire de la République en Polynésie Française; Tere Bishop; Mrs Diane McKegg; Albert Varney, Philippe Raust, Jacques Florence and Bill Sykes. Also, the residents of Rimatara, especially Simeon Tehio who greatly assisted us with our fieldwork, and Hirama Hatito who clarified the community attitude to the 'Ura. 


\section{References}

Atkinson, I. A. E. (1985) The spread of commensal species of Rattus to oceanic islands and their effects on island avifaunas. Pp. 35-81 in P. J. Moors, ed. Conservation of island birds. Cambridge, U.K.: International Council for Bird Preservation (Techn. Publ. 3).

Brunner, P. L. (1972) Field guide to the birds of French Polynesia. Honolulu: Bernice P. Bishop Museum, Pacific Scientific Information Centre.

Forshaw, J. M. (1978) Parrots of the world. Second edition. Melbourne: Lansdowne Editions.

Hiroa, Te Rangi, (Peter H. Buck) (1944) Arts and crafts of the Cook Islands. Bishop Mus. Bull. 179: 1-533.

McCormack, G. (1991) Day and night biters - Cook Islands Mozzies. Cook Islands News, 27 March 1991.

McCormack, G. (1993) Mynas for stick-insects in the Outer Islands. Cook Islands News, 2 October 1993.

Rowe, S. (1993) The Tanga'eo Research Project, Mangaia, Cook Islands. Unpublished Report for the Cook Islands Natural Heritage Project.

Savage, S. (1962) A dictionary of the Maori language of Rarotonga. Wellington, New Zealand: Government Printer de Polynésie Française.

Seitre, R. and Seitre, J. (1991) Causes de disparition des oiseaux terrestres de Polynésie Française. Nouméa: South Pacific Regional Environment Programme (Occasional Paper Series 8).

Service de l'Urbanisme (1988) Rimatara, Archipel des Australes. 1 : 10,000. Tahiti: Ministére de l'Urbanisme.

Steadman, D. W. (1985) Fossil birds frm Mangaia, southern Cook Islands. Bull. Brit. Orn. Club 105: 58-66.

Steadman, D. W. (1991) Extinct and extirpated birds from Aitutaki and Atiu, Southern Cook Islands. Pacific Sci. 45(4): 325-347.

Steadman, D. W., Greiner, E. C. and Wood, C. S. (1990) Absence of blood parasites in indigenous and introduced birds from the Cook Islands, South Pacific. Conserv. Biol. 4: $398-404$.

Townsend, C. H. and Wetmore, A. (1919) Reports on the scientific results of the Expedition to the Tropical Pacific in charge of Alexander Agassiz, on the US Fish. Comm. Steamer Albatross from August 1899 to March 1900, under Commander J. F. Moser, USN commanding. Bull. Mus. Comp. Zool. 63: 151-225.

van Riper, C., van Riper, S. G., Goff, M. L. and Laird, M. (1986) The epizootiology and ecological significance of malaria in Hawaiian land birds. Ecol. Monogr. 56: 327-344.

Wilson, K-J. (1993) Observations on Kurāmo'o (Vini peruviana) on Aitutaki Island, Cook Islands. Notornis 40: 71-75.

GERALD McCORMACK and JUDITH KÜNZLÉ

Cook Islands Natural Heritage Project, Prime Minister's Department, Rarotonga, Cook Islands. 